\title{
Growth Kinetics, Light Dynamics, and Lipid Production in Microalgae from Sugar-Mill Ponds
}

\author{
B. C. Benson, ${ }^{a}$ B. J. Meyer, ${ }^{\text {b }}$ R. K. Bajpai, \\ D. D. Gang, ${ }^{d}$ S. T. Dufreche, ${ }^{d}$ and M. E. Zappi ${ }^{a, c,}$ \\ ${ }^{a}$ Energy Institute of Louisiana \\ bSchool of GeoSciences \\ 'Department of Chemical Engineering \\ ${ }^{\mathrm{d} D e p a r t m e n t}$ of Civil Engineering \\ University of Louisiana at Lafayette (UL) \\ PO Box 44130, Lafayette, LA, USA 70504
}

doi: 10.15255/CABEQ.2016.852

Original scientific paper

Received: March 2, 2016

Accepted: September 12, 2016

\begin{abstract}
Sugar-mill wastewaters have potential to support microalgal biomass production for use as a biofuel feedstock (lipid source). Growth kinetics, light dynamics, and lipid production in multispecies-microalgae cultures collected from a sugar-mill pond are reported in this paper. Lipid content of the microalgae collected from the pond water was $14.5 \%$ $(w / w)$. Culturing the same microalgae in a photobioreactor on the pond wastewater supplemented with Gillard's $\mathrm{F} / 2$ and $\mathrm{CO}_{2}$, and irradiated with 151 to $337 \mu \mathrm{mol} \mathrm{s}^{-1} \mathrm{~m}^{-2}$ artificial light produced cells with lipid contents of $11 \%(w / w)$ at $25^{\circ} \mathrm{C}, 35 \%(\mathrm{w} / \mathrm{w})$ at $31{ }^{\circ} \mathrm{C}$, and $28.6 \%(\mathrm{w} / \mathrm{w})$ at $33{ }^{\circ} \mathrm{C}$. The maximum specific growth rates $\left(\mu_{\text {max }}\right)$ at $25{ }^{\circ} \mathrm{C}, 31^{\circ} \mathrm{C}$, and $33{ }^{\circ} \mathrm{C}$ were $0.64 \mathrm{~d}^{-1}, 2.5 \mathrm{~d}^{-1}$, and $2.7 \mathrm{~d}^{-1}$, respectively. Under these conditions, cell densities as high as $1020 \mathrm{~g}$ cell dry mass $(\mathrm{CDM}) \mathrm{m}^{-3}$ were recorded. Total scalar irradiance attenuation coefficient $\left(k_{0}\right)$ was $0.275 \mathrm{~m}^{-1}$ in clear water and $30.5 \mathrm{~m}^{-1}$ in the dense culture. The attenuation coefficient of irradiance due to biomass $\left(k_{\mathrm{B}}\right)$ was found to be a linear function of cell concentration in this work.
\end{abstract}

Key words:

wastewater, photobioreactor, light attenuation, biofuels, alternative energy

\section{Introduction}

The development of high tonnage microalgae production using cost-competitive methods is of great interest to the renewable biofuels industry ${ }^{1-4}$ due to the ability of microalgae to form significant quantities of lipids utilizing solar energy while capturing carbon dioxide or even waste carbohydrates. Microalgae have higher productivity than traditional oil crops because they can double their mass every 4 to 24 hours, and generally have 20 to $75 \%$ oil content in biomass on $\mathrm{w} / \mathrm{w}$ basis ${ }^{2,5,6}$. A decade ago, the production costs of microalgae ranged from $\$ 20$ - \$1,000 ( $\mathrm{kg} \mathrm{CDM})^{-1}$ depending on culture system type and $\operatorname{size}^{7}$. As a result, much of the current research on microalgae production has been focused on reducing costs associated with cell production, dewatering, and lipid extraction. It has been estimated that the production cost of microalgal biomass cultured with currently available technology could be lowered to approximately $\$ 2.95-\$ 3.80$ $(\mathrm{kg} \mathrm{CDM})^{-1}$ if carbon dioxide is available at no cost from $\mathrm{CO}_{2}$ emissions, and even lower, provided the

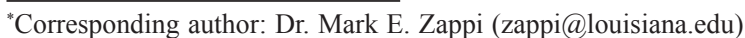

nutrients available in wastewaters are utilized in production facilities scaled to 10,000 tons $\mathrm{CDM} / \mathrm{y}$ using natural light ${ }^{7,8}$. Such conditions, however, have not been met in any of the existing facilities around the world ${ }^{2,9}$. Strategies suggested for reducing production costs of biofuels, such as integrating biodiesel as co-product of a bio-refinery ${ }^{10}$, integrating production of polyhydroxybutyrate (PHB) or other biodegradable plastics with sugar-mill operations $^{11}$, use of bagasse and other cellulosic trash in sugar mills for second generation biofuels ${ }^{12}$, and production of biocompatible / biodegradable green plastics (polyhydroxyalkanoates PHAs) from the biodiesel byproduct glycerol ${ }^{13}$, may be utilized with algae cultivation as well, but these have yet to be explored.

Lately, co-location of microalgae culturing facilities at or near sugar mills has potential to address the above limitations ${ }^{14-16}$. A typical sugar mill has a raw product staging area where the incoming cane is cut and crushed by roller mills to release the sugar juice from the fibers ${ }^{17,18}$. The fibers are further dewatered and used, in most cases, as fuel for an on-site power-generating plant. The sugar juice is purified via chemical addition, and the mud-precip- 
itants are removed via filtration/sedimentation; the purified sugar juice is then processed into massecuite for final separation as sugar crystals and molasses. Mud-precipitates are usually sent to treatment/holding ponds, normally less than 9 acres in size. Most sugar mills have 2 to 4 ponds on-site. Effluents from these ponds can be used to cultivate microalgae ${ }^{19-21}$. As an aside, the molasses, sweetmuds, and other carbon-based wastes may also be used to support the mixotrophic microalgal cultures $^{18}$. The power plants, as they combust the fibers, emit carbon dioxide that can be a carbon source for autotrophic algae. Moreover, these mills have a large capital investment in dewatering equipment that sits idle over half the year during the non-grinding season. The dormant process equipment represent basically the same configurations needed for microalgae dewatering and drying. During these non-grinding months (March to September), higher ambient temperatures are conducive also to greater algal biomass production.

The concept of co-location was explored by Lohrey and Kochergin ${ }^{16}$ through simulation studies of material and energy balances using the Sugars ${ }^{\mathrm{TM}}$ modeling program. Their findings indicated that a sugar mill producing 10,000 ton sugar/day (TPD) could support production of 30,000 tons CDM microalgae/y in 530 ha algal pond area, yielding 5.8 million L of biodiesel (B100)/y, and reduce $\mathrm{CO}_{2}$ emissions also by $15 \%$ without requiring any fossil fuel. This study recognized that most of the inherent uncertainty of the model was due to the lack of data on modeling parameters, and pointed out the need for further research on algal species native to the sugar-mill location for their production rates and lipid content. The optimized microalgae production rates require the understanding of growth kinetics and light dynamics.

An additional concern in microalgae-based biofuel production is the need for large amounts of water and nutrients ${ }^{22-24}$. While phosphorus $(\mathrm{P})$ in effluent waters is considered a pollutant, it is becoming a depleted resource also ${ }^{22,25}$. For these two reasons, research exploring the potential for using wastewaters to produce microalgae biomass for the biofuel industry is being encouraged by the U.S. Department of Energy ${ }^{3}$. The Southeastern U.S. Gulf Coast Region has been identified through GIS modeling studies to be an optimal location for algae biomass production $^{24}$. This region has a large number of sugar mills also that produce large volumes of wastewater containing appreciable amounts of nutrients suitable for cultivation of microalgae.

The majority of microalgal species are phototrophic ${ }^{26,27}$. The photoautotrophic and mixotrophic cultures depend on photosynthetically available radiation (PAR) to drive the photosynthetic process ${ }^{28}$, and maximizing light utilization is of primary importance to achieve the highest level of production in microalgal systems ${ }^{29-32}$. At high irradiance levels, growth of microalgae is photo-inhibited ${ }^{33-35}$. Photo-oxidation begins at average irradiances greater than $I_{\text {opt}}$, causing temporary or even permanent damage to the electron transfer chain of Pigment System II in cells ${ }^{29}$. Photo-inhibition has been reported in outdoor cultures of Spirulina under natural light intensities that are $10 \%$ of full sunlight ${ }^{36}$. In photobioreactors, literature reporting photo-inhibition is scarce since the artificial light sources used in such reactors usually have light intensity approximately 10-20\% that of natural sunlight ${ }^{37}$.

Steele's equation and similar models are used to model growth $(\mu)$ in a photoautotrophic culture:

$$
\mu=\mu_{\max } \frac{I_{a}(P A R)}{I_{o p t}(P A R)} e^{1-I_{a}(P A R) / I_{o p t}(P A R)}
$$

Here, $\mu$ is the specific growth rate $\left(\mathrm{d}^{-1}\right), \mu_{\max }$ is the maximum specific growth rate $\left(\mathrm{d}^{-1}\right), I_{a}(\mathrm{PAR})$ is the average irradiance in the culture, and $I_{\text {opt }}$ (PAR) the scalar irradiance $\left(\mu \mathrm{mol} \mathrm{s} \mathrm{s}^{-1} \mathrm{~m}^{-2}\right)$ associated with $\mu_{\max }$. Collecting empirical data on these parameters is necessary for modeling, defining optimum conditions, and understanding production under various growth conditions. The design and operational factors that influence these parameters include depth of culture, mixing rate (cell light/dark cycling frequency), dilution rate, nutrients, temperature, salinity, and distance of light source from the culture surface in the case of artificially lighted systems ${ }^{10,27,29,30,38-42}$. Numerical models, such as those developed by Benson et al. ${ }^{7,37,43}$ and Lohrey and Kochergin ${ }^{16}$ are needed to simulate and optimize microalgal production in sugar-mill wastewaters.

This paper reports results of investigation of growth kinetics, light dynamics, and lipid content of native microalgal species endemic to a sugar-mill wastewater pond. These experiments were conducted over a temperature range typical of a wastewater pond during daylight hours of the non-grinding season at a sugar mill. The specific objectives of this work were to determine:

- The light attenuation parameters in the sugar-mill wastewater.

- The growth dynamics of microalgae of the sugar-mill wastewater cultivated in a photobioreactor supplied with nutrients (Gillard's F/2) and $\mathrm{CO}_{2}$ over the range of temperatures.

- The lipid content of microalgae in the wastewater and those cultivated in the photobioreactor.

Preliminary estimates of parameters needed to model microalgae production from the eutrophic waters are reported here. While beyond the scope of this work, this information is expected to lead to 
future research and model simulations to forecast efficiency, optimization of pond configuration, and economics of algal production at sugar production facilities.

\section{Materials and methods}

Wastewater: Samples were collected from a sugar-mill pond in St. Mary Parish, Louisiana, USA in ethanol-sterilized containers using a hand-siphon pump at discharge outlet 12-inches below the surface. Average temperature of the pond water at collection times was $31{ }^{\circ} \mathrm{C}$. The samples were transported directly to the lab and used in studies. The waters had $0.77 \mathrm{mg} \mathrm{L}^{-1} \mathrm{PO}_{4}-\mathrm{P}$ but no measurable amount of $\mathrm{N}$.

Photobioreactor: A New Brunswick Scientific 1-L working volume bioreactor (Model F-1000) was used in this study in batch mode of operation. Internal diameter of the tank was $10 \mathrm{~cm} . \mathrm{pH}$ in the bioreactor was controlled between 7.5 and 8.5 by continuous supply of $\mathrm{CO}_{2}$ which was adjusted every 4 hours. Nutrients (F/2 medium listed in Table 1; Kent Marine, Inc.) were added to the wastewater in the form of A and B solutions (1-mL each, full strength) at the start of each run. This achieved target concentrations of $4 \mathrm{mg} \mathrm{NO}_{3}-\mathrm{N} \mathrm{mg} \mathrm{L}^{-1}$ and $\mathrm{PO}_{4}-\mathrm{P}$ to $<2.25 \mathrm{mg} \mathrm{L}^{-1}$. Temperature in the reactor was controlled by circulating water from a water bath

Table 1 - Pro-Culture F/2: For composition, see http://www.ccap.ac.uk/media/documents/f2.pdf

\begin{tabular}{l|c}
\hline \multicolumn{1}{c}{ Ingredient } & Quantity $(\% \mathrm{w} / \mathrm{w})$ \\
\hline \multicolumn{2}{c}{$\begin{array}{c}\text { Media Part A: Sources of nutrients are iron EDTA, } \\
\text { manganese EDTA, sodium EDTA, cobalt chloride, zinc } \\
\text { EDTA, copper EDTA, sodium molybdate. }\end{array}$} \\
\hline $\begin{array}{ll}\text { Iron (minimum) } \\
\text { Manganese (minimum) }\end{array}$ \\
Cobalt (minimum) \\
Zinc (minimum) \\
Copper (minimum) \\
Molybdenum (minimum)
\end{tabular}

Media Part B: Sources of nutrients are monosodium phosphate, thiamine hydrochloride (vitamin $\mathrm{B}_{1}$ ), vitamin $\mathrm{B}_{12}$, biotin.

\begin{tabular}{ll}
\hline Available nitrogen & 15.0 \\
Available phosphate $\left(\mathrm{P}_{2} \mathrm{O}_{5}\right)$ & 2.0 \\
Soluble potash $\left(\mathrm{K}_{2} \mathrm{O}\right)$ & 0.0 \\
Vitamin $\mathrm{B}_{1}$ & 0.07 \\
Vitamin $\mathrm{B}_{12}$ & 0.0002 \\
Biotin & 0.0002 \\
\hline
\end{tabular}

through heat-exchange coils in the reactor. A 120-W Sylvania Spot-GRO light bulb was used for artificial sunlight irradiation to the bioreactor contents.

Biomass density: Cell concentration was measured as optical density (OD) in samples at $750 \mathrm{~nm}$

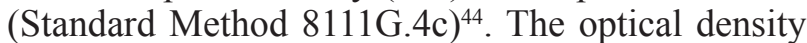
values were converted into cell density as $\mathrm{g} \mathrm{CDM} \mathrm{m}^{-3}$ with the help of the following linear relationship with $r^{2}>0.98$, which was obtained from a calibration curve of cell density vs. OD prepared using the cells grown in this work:

$$
\text { Cell density }\left(\mathrm{g} \mathrm{CDM} \mathrm{m}^{-3}\right)=2.056 \mathrm{OD}_{750}
$$

Lipid content in cells: Lipids were extracted from the microalgae using Bligh and Dyer ${ }^{45}$ method. Replicate samples were not evaluated due to limited quantity of cells produced in these experiments.

Photosynthetic Available Radiation (PAR): PAR was measured using a spherical quantum sensor (Li-Cor, Model LI-193SA) in cell suspensions created by diluting the final broths $(0 \%, 25 \%, 50$ $\%, 75 \%$, and $100 \%$ resulting in biomass concentrations ranging from $0-1.020 \mathrm{~g} \mathrm{CDM} \mathrm{m}^{-3}$ ) from the growth studies. Instantaneous readings, proximal, central, and distal to the light source, were recorded at different depths of light once the quantum sensor had stabilized. The measurements of irradiation $\left(I_{7}\right)$ at different depths $(Z)$ were processed using the Lambert-Beer Law (equation 3 ) to determine the surface irradiance $\left(I_{O S}\right)$ and the overall scalar attenuation coefficient $\left(k_{0}\right)$.

$$
I_{Z}(\mathrm{PAR})=I_{O S}(\mathrm{PAR}) \mathrm{e}^{-k_{0} Z}
$$

Here $I_{Z}(\mathrm{PAR})$ is the scalar irradiance at light depth $Z\left(\mu \mathrm{mol} \mathrm{s}^{-1} \mathrm{~m}^{-2}\right), I_{\text {os }}$ is the scalar irradiance on surface, $k_{0}$ is the overall scalar attenuation coefficient $\left(\mathrm{m}^{-1}\right)$, and $Z$ is light depth $(\mathrm{m})$.

The overall attenuation coefficient $\left(k_{0}\right)$ was related to the biomass concentration, $X\left(\mathrm{~g} \mathrm{CDM} \mathrm{m}^{-3}\right)$, by the following equation to determine the water and biomass attenuation coefficients:

$$
k_{0}=k_{\mathrm{W}}+k_{\mathrm{B}} X
$$

Here $k_{\mathrm{W}}$ is the water attenuation coefficient $\left(\mathrm{m}^{-1}\right)$ and $k_{\mathrm{B}}$ is the biomass attenuation coefficient $\left(\mathrm{m}^{2} \mathrm{~g}^{-1}\right)$. In a culture, it is assumed that the dissolved matter was present at low concentration, uniformly distributed, and relatively unchanged during culturing, and thus could be lumped with the attenuation of water. It was also assumed the ratio of Chlorophyll a to total suspended solids (TSS) would be relatively constant. Therefore, the attenuation due to the microalgae could be represented as a function of the overall TSS rather than divided between Chlorophyll a and non-pigmented TSS. 
Growth studies: Three growth studies were performed in the photobioreactor at $25{ }^{\circ} \mathrm{C}, 31{ }^{\circ} \mathrm{C}$, and $33{ }^{\circ} \mathrm{C}$. In each case, the pond-derived algal cultures were utilized to inoculate the supplemented pond water. Samples were collected at 4-hour intervals for determination of biomass density. Lipid content in the cells was determined at the end of the experiments. The cell mass concentration data were used to calculate the specific growth rate of cells $[\mu$ $=\mathrm{d}(\ln X) / \mathrm{d} t]$. The average scalar irradiance in the reactor $\left[I_{a}(\mathrm{PAR})\right]$ at each sampling time during the growth studies was calculated by the equation (5), as per Molina Grima et al. ${ }^{30}$ :

$$
I_{a}(P A R)=\frac{1}{d} \int_{0}^{d} I(Z) \mathrm{d} Z=\frac{I_{o s}\left(1-e^{-k_{0} d}\right)}{k_{0} d}
$$

Here $d$ is the light depth $(0.1 \mathrm{~m})$ in the photobioreactor used, $I_{O S}$ is the surface irradiance estimated using PAR measurements, and $k_{0}$ is the overall attenuation coefficient in the culture at specific sampling time (calculated using biomass concentration in the samples, and $k_{\mathrm{w}}$ and $k_{\mathrm{B}}$ estimated by PAR measurements).

These data were then used to calculate maximum net specific growth rate $\left(\mu_{\max }\right)$ for experiments at various temperatures $\left(25{ }^{\circ} \mathrm{C}, 31{ }^{\circ} \mathrm{C}\right.$, and $\left.33^{\circ} \mathrm{C}\right)$ culture conditions.

\section{Results and discussion}

\section{Light attenuation characteristics in microalgal cultures from the sugar-mill wastewater}

Three quantum sensor readings, proximal, central, and distal to the light source, were taken and averaged at different depths in the fermenter across its $0.1 \mathrm{~m}$ diameter in suspension containing biomass concentrations ranging from $0-1.020 \mathrm{~g} \mathrm{CDM} \mathrm{m}^{-3}$. These observations are shown in Figure 1. In all the cases except for clear solution (zero biomass concentration), irradiance dropped rapidly as the light path length increased and incremental loss of irradiance decreased with increasing biomass concentrations. For the light-path of $0.1 \mathrm{~m}$ in this photobioreactor, light attenuation by water was small. This is in agreement with the suggestion of Molina-Grima et al. ${ }^{30}$ that light attenuation by water may be neglected for light path lengths up to $0.15 \mathrm{~m}$. Acien-Fernandez et al. ${ }^{28}$ also neglected light attenuation in absence of biomass within $0.05 \mathrm{~m}$ diameter tubes. In deeper culture systems with longer path length, attenuation due to water cannot be neglect$\mathrm{ed}^{37}$. Although there is a possibility that the attenuation curves are biphasic with an increased attenuation rate in the shallow depths where wavelengths of low energy are absorbed ${ }^{41,46}$, an assumption is often made that the attenuation coefficient is a con$\operatorname{stant}{ }^{46}$.

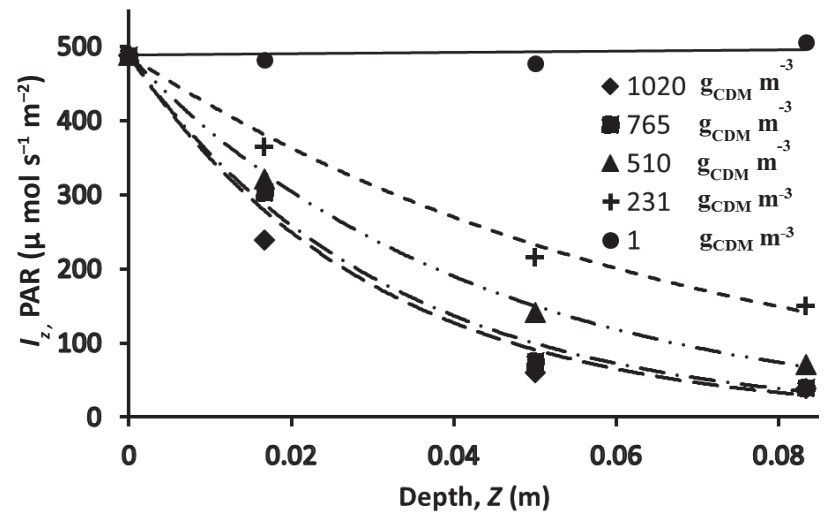

Fig. 1 - Scalar irradiance as a function of light path depth at different biomass concentrations in algal suspensions cultured in the photobioreactor

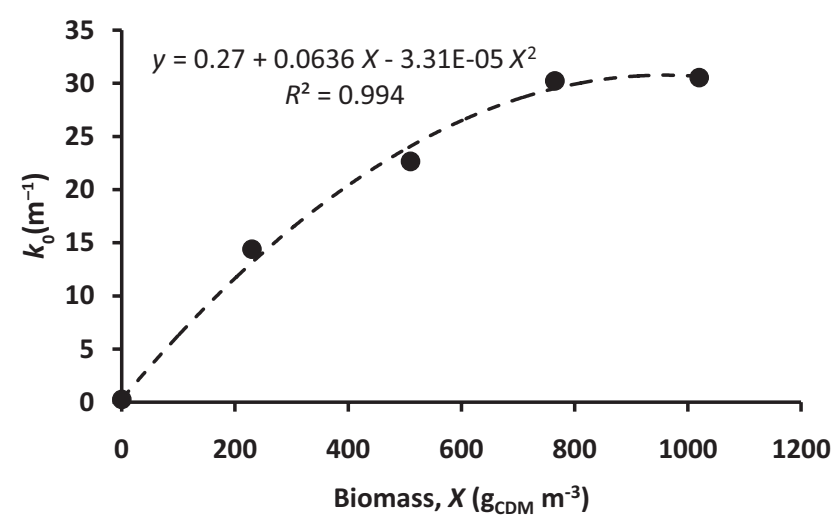

Fig. 2 - Dependence of the light attenuation coefficients, $k_{0^{\prime}}$ on biomass concentration

The experimental data presented in Figure 1 were used to evaluate the attenuation coefficients $k_{0}$ using semi-log plots per equation (3). The data regressions yielded $k_{0}$ values ranging from $0.275 \mathrm{~m}^{-1}$ for clear water to $30.5 \mathrm{~m}^{-1}$ for biomass suspensions of $1.020 \mathrm{~g} \mathrm{CDM} \mathrm{m}^{-3}$ cell density $\left(r^{2}>0.99\right.$ for all cases). These values are plotted against biomass concentrations in Figure 2. In this figure, second-order polynomial regression line has been shown with corresponding regression expression and the correlation coefficient. It is clear that the biomass attenuation coefficient $\left(k_{\mathrm{B}}\right)$ of equation (4) is itself a function of biomass concentration. The second order fit suggests that the biomass attenuation coefficient is linearly dependent on biomass concentration in the ranges ( $X$ up to $1000 \mathrm{~g} \mathrm{CDM} \mathrm{m}^{-3}$ ), likely to be encountered in outdoor open algae cultivation systems $\left(k_{\mathrm{B}}=0.0636-3.31 \cdot 10^{-5} X\right)$. Since the light path depths in practice may be comparable or even greater than those used in this study, it is recommended to use the biomass concentration-dependent biomass attenuation coefficients.

Using the biomass concentration dependency established here, the biomass attenuation coeffi- 
cient, $k_{\mathrm{B}}$, was determined to be $0.0597 \mathrm{~m}^{2} \mathrm{~g}^{-1} \mathrm{CDM}$ for average biomass concentration in the range of 68 to $167 \mathrm{~g} \mathrm{CDM} \mathrm{m}^{-3}$. This is comparable to the value of $k_{\mathrm{B}}=0.0575 \mathrm{~m}^{2} \mathrm{~g}^{-1} \mathrm{CDM}$ found by Benson et al. ${ }^{37}$ in cultures of Selenastrum capricarnutum in HISTAR where biomass concentrations ranged from 68 to $167 \mathrm{~g}^{-1} \mathrm{CDM} \mathrm{m}^{-3}$. Rebolloso-Fuentes et $a l^{47}$ also reported biomass light attenuation coefficients ranging from 0.038 to $0.041 \mathrm{~m}^{2} \mathrm{~g}^{-1} \mathrm{CDM}$ for outdoor cultures of Porphyridium cruentum. Molina-Grima et al. ${ }^{30,41}$ estimated the coefficients in the range of $0.0369-0.1035 \mathrm{~m}^{2} \mathrm{~g}^{-1} \mathrm{CDM}$ for three different microalgal species cultured under outdoor conditions.

While direct comparison of the literature values to those obtained in this study is difficult due to differences in the method of estimation, it is evident that artificial illumination produces attenuation patterns similar to those obtained for natural sunlight ${ }^{37}$. Furthermore, there appears to be a negative correlation between $k_{\mathrm{B}}$ and biomass concentration $(X)$, which might be expected due to an increase in self-shading with increased biomass density, concurrent with the increased probability of overlap of self-shaded cells at higher concentrations. This suggests that a more accurate model of light attenuation in deep cultures with high biomass density is in the form of equation (4) with the parameter $k_{\mathrm{B}}$ a function of $X$.

Using the estimated values of surface irradiance $\left(I_{O S}\right)$ and the light attenuation coefficient $\left(k_{0}\right)$, average PAR values in a photobioreactor of $0.1 \mathrm{~m}$ light depth were calculated using equation (5) at the different biomass concentrations used in the above studies. The calculated average PAR values have been plotted against cell concentration $(X)$ in Figure 3 . From this, the following functional inverse hyperbolic relationship was developed for use within the experimental range of cell concentrations:

$$
\frac{I_{a}}{I_{O S}}=1-0.86 \frac{X}{221+X} \quad\left(r^{2}=0.99\right)
$$

Such inverse (albeit exponential) relationships have been used by several researchers as well ${ }^{28,37,48}$. Although such a direct relationship between average PAR and cell density is not as good as the indirect one represented by equations (3-5), its simplicity led to using equation (6) to estimate average PAR in the photobioreactor at the different sampling times during growth studies reported next.

The results of this light attenuation study also suggest that little penetration of light occurs beyond a very narrow depth in high density cultures. The dense cultures reactors, therefore, must either be narrow or have considerable mixing across depth to ensure that cells are frequently exposed to light for photosynthesis. Many of the outdoor systems today

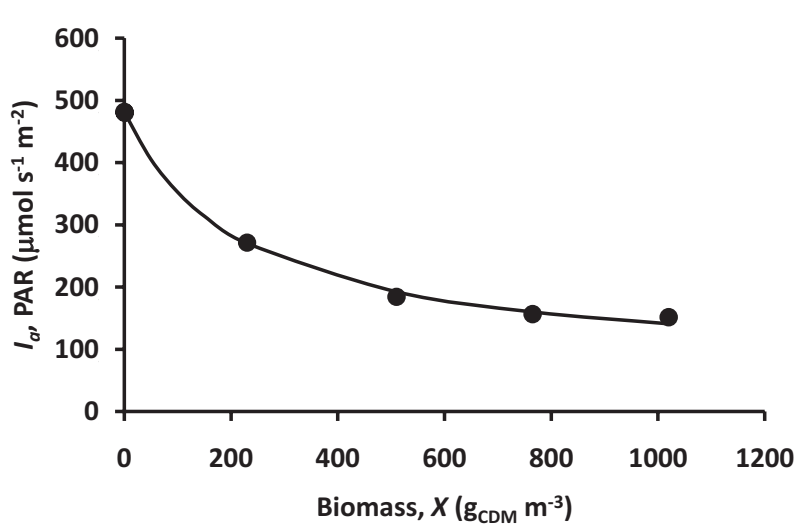

Fig. 3 - Relationship between the average PAR (calculated) and biomass concentration in the photobioreactor during growth studies of microalgae from sugar-mill retention pond cultured on the sugar-mill wastewater

are deeper than the light penetration point, and thus have large dark zones that result in dilute cultures and high dewatering costs.

\section{Growth dynamics of microalgae of the sugar-mill wastewater in a photobioreactor}

Growth dynamics for microalgal communities in the sugar-mill retention pond wastewater were studied in the photobioreactor at three different temperatures. These temperatures $\left(25,31\right.$, and $\left.33{ }^{\circ} \mathrm{C}\right)$ were selected to represent the range of temperatures observed in the pond during the months the mill is not in operation. Temperature of pond waters during water collection was $31{ }^{\circ} \mathrm{C}$. The microalgae was grown in the bioreactor until the cultures reached stationary growth phase, which took about 4 to 5 days. Throughout the growth studies, samples were collected at 4-hour intervals, and OD readings in these samples were used to calculate the dry weight biomass concentrations using equation (2). Average PAR values within the cultures were also calculated using equation (6). The cell growth curve and the calculated PAR values are shown in Figure 4 for cultivation temperature of $33{ }^{\circ} \mathrm{C}$.

Exponential growth, observed by a semi-log plot of cell dry weight concentration against time, was observed only from $35^{\text {th }}$ to $42^{\text {nd }} \mathrm{h}$, representing a maximum specific growth rate of $2.7 \mathrm{~d}^{-1}$ at this temperature. During this period, average PAR in the reactor was $340 \mathrm{mmol} \mathrm{s}^{-1} \mathrm{~m}^{-2}$. Beyond this period, the culture showed continued growth of cells to cell density of $1020 \mathrm{~g} \mathrm{CDM} \mathrm{m}^{-3}$ at the end of growth phase. During this period, average PAR values decreased from $400 \mathrm{mmol} \mathrm{s}^{-1} \mathrm{~m}^{-2}$ to $100 \mathrm{mmol} \mathrm{s}^{-1} \mathrm{~m}^{-2}$. Linear growth continued until biomass concentration of $989 \mathrm{~g} \mathrm{CDM} \mathrm{m}^{-3}$ was achieved; PAR flux at this point was $109 \mathrm{mmol} \mathrm{s}^{-1} \mathrm{~m}^{-2}$. Because of the efficient mixing in the bioreactor, biomass concentration continued to increase even at average PAR lev- 
els below what would be expected to be photolimiting.

The experiments at $25{ }^{\circ} \mathrm{C}$ and at $31{ }^{\circ} \mathrm{C}$ gave similar results, although the maximum cell densities obtained in these experiments were considerably lower due to unanticipated disruptions during experiments. The maximum specific growth rates at these temperatures and their standard deviations are shown in Figure 5. In this figure, the average specific growth rate and its estimated standard deviation is also presented considering that $25-33{ }^{\circ} \mathrm{C}$ represents the anticipated temperature range during operational period. The maximum cell densities achieved during the different experiments are shown in Figure 6. The cell density in pond water is also shown in this figure.

The $\mu_{\max }$ was observed at different photo flux for each temperature investigated, at the average PAR $(I)$ ranging from 151 to $362 \mathrm{mmol} \mathrm{s}^{-1} \mathrm{~m}^{-2}$, during which cells grew exponentially. In prior studies $^{37}$ of light dynamics and growth of Selenastrum capricarnutum under metal halide lamps, approximately $95 \%$ of $\mu_{\max }$ was observed over a PAR range of 160 to $530 \mathrm{mmol} \mathrm{s}^{-1} \mathrm{~m}^{-2}$ with the optimum irradiance $\left(I_{o p t}\right)$ at $391 \mathrm{mmol} \mathrm{s}^{-1} \mathrm{~m}^{-2}$; photo-limitation and photo-inhibition occurred at irradiance levels below and above this range, respectively.

Results of this study indicate that, in a wellmixed culture of sugar mill microalgae, growth rates near maximum can be achieved if the $I_{a}$ for the system is between 150 to $400 \mathrm{mmol} \mathrm{s}^{-1} \mathrm{~m}^{-2}$. In these experiments, cell concentrations reached 1030 $\mathrm{g} \mathrm{CDM} \mathrm{m}^{-3}$. The total light attenuation coefficient $\left(k_{0}\right)$ at this concentration was $30.5 \mathrm{~m}^{-1}$. Cell specific growth rate was highest for the culture at $33{ }^{\circ} \mathrm{C}$ $\left(\mu_{\max }=2.7 \mathrm{~d}^{-1} ; p<0.0001\right)$, whereas, the cultures at $31^{\circ} \mathrm{C}$ and $25^{\circ} \mathrm{C}$ had $\mu_{\max }$ values of $2.5 \mathrm{~d}^{-1}$ and 0.64 $\mathrm{d}^{-1}$, respectively $(p<0.0001)$ (see Figure 5). There was a significant difference between the $\mu_{\text {ob- }}$ served at the higher temperatures and that at $25{ }^{\circ} \mathrm{C}$, indicating that temperatures above $31{ }^{\circ} \mathrm{C}$ may be more conducive to biomass production. In literature $^{49}, \mu_{\max }$ values as high as $2.2 \mathrm{~d}^{-1}$ have been reported for Dunaliella tertiolecta at $28{ }^{\circ} \mathrm{C}$. Seven marine microalgae Pavlova lutheri, Isochrysis galbana, Tetraselmis suecica, Chaetoceros calcitrans, Phaeodactylum tricornutum, Rhodomonas sp., and Heterosigma akashiwo were reported to have similar growth $\operatorname{rates}^{50}$. The average observed surface temperature in the sugar-mill pond was $31{ }^{\circ} \mathrm{C}$, which probably explains high growth rates at this temperature and the even higher growth rates at $33^{\circ} \mathrm{C}$. It is safe to assume that the microalgae community from the wastewater pond was adapted to $31{ }^{\circ} \mathrm{C}$ and is more thermophilic than typical. Certain freshwater microalgae species, such as Selenastrum capricarnutum, have optimal growth at $27{ }^{\circ} \mathrm{C}^{51,52}$,

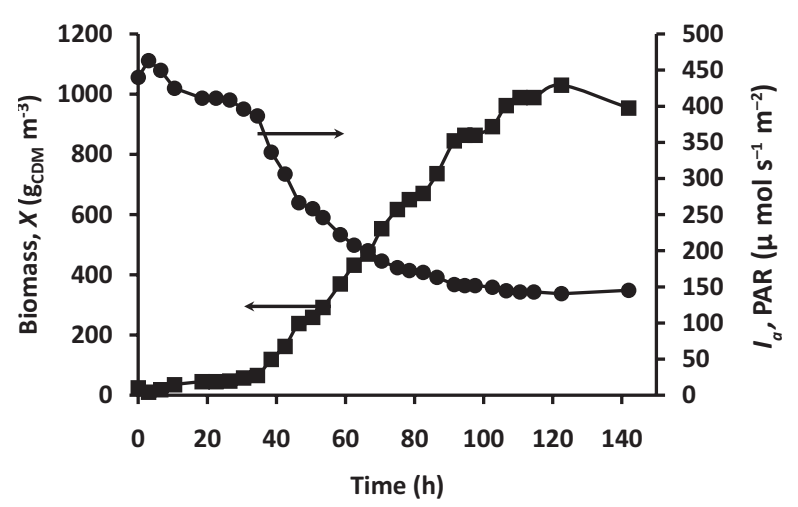

Fig. 4 - Changes in the biomass concentration and average PAR in the fermenter during $33{ }^{\circ} \mathrm{C}$ growth study of sugar-mill retention pond microalgae cultured on wastewater

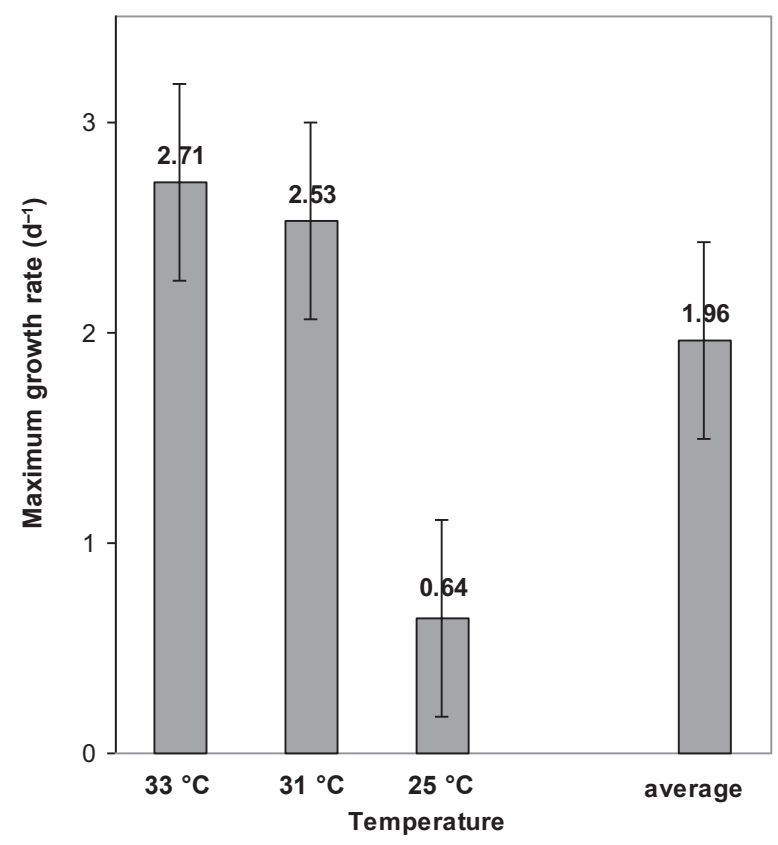

Fig. 5 - Maximum net specific growth rates (with standard error bars) observed at various temperatures for growth studies of sugar-mill retention pond microalgae cultured on wastewater

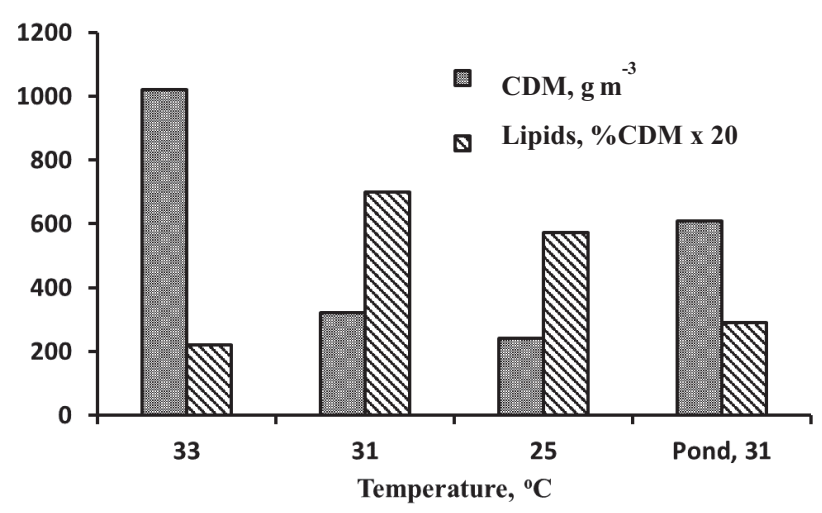

Fig. 6-Cell dry weight and lipid content as percent of biomass dry weight in fermenter under three different temperatures and in microalgal cells collected from surface waters of the sugar-mill wastewater pond 
and $28{ }^{\circ} \mathrm{C}$ is optimum for Dunaliella tertiolecta ${ }^{49}$. Other reports in literature ${ }^{53}$ suggest that optimal temperatures are generally between $12{ }^{\circ} \mathrm{C}$ and $40^{\circ} \mathrm{C}$, depending on the strain.

\section{Lipid content of microalgae in the wastewater}

Lipid contents of the cells produced during these studies are presented in Figure 6. Temperature of cultivation had a strong effect on intracellular lipid content with cells cultivated at $33{ }^{\circ} \mathrm{C}$, reporting significantly lower lipid fraction $(11 \% \mathrm{w} / \mathrm{w})$ compared to those cultivated at $31^{\circ} \mathrm{C}(35 \% \mathrm{w} / \mathrm{w})$ and at $25{ }^{\circ} \mathrm{C}(28 \% \mathrm{w} / \mathrm{w})$. The media used for these cultivations was supplemented with Gillard's F/2 medium and $\mathrm{CO}_{2}$. On the other hand, cells collected from the pond had lipid fraction of $14.5 \%(\mathrm{w} / \mathrm{w})$. These lipid fractions are moderate compared to the lipid fractions reported in literature. Several cultured microalgal strains have been shown to produce $20-50 \%$ of their CDM as lipids ${ }^{24,54}$. According to Metzger and Largeau 5 , Botryococcus braunii have lipid content above $70 \%$ CDM. Since the pond is carbon-rich (from bagasse) and the pond temperature was $31^{\circ} \mathrm{C}$ (which would be conducive to high growth rates and nutrient uptake), the pond waters were considered as nutrient-limited, as non-detectible phosphate testing results indicated. Stress due to temperature and reduced nitrogen has been reported in other studies to increase the cell lipid content ${ }^{53}$ and our own laboratory studies also support this observation. However, growing the mixed algal culture in the laboratory with nutrients added (Figure 6) resulted in significantly more lipids in cells compared to that in pond samples (both at $31^{\circ} \mathrm{C}$ ). According to Barajas-Solano et al..$^{6}$, it is necessary that the best sources as well as ratio of carbon and nitrogen be found to maximize biomass and total lipid production.

\section{Conclusions}

The parameters for modeling light dynamics and growth kinetics in a sugar mill wastewater pond have been estimated. Highest $\mu_{\max }$ values $2.5 \mathrm{~d}^{-1-}$ $2.7 \mathrm{~d}^{-1}$ were observed with the cultures at $31{ }^{\circ} \mathrm{C}$ and $33^{\circ} \mathrm{C}$. This indicates that the microalgae community in the pond, during the summer, is adapted to the warmer temperature. The $\mu_{\max }$ was observed at different photo flux for each growth study with $I_{a}$ ranging from 151 to $362 \mathrm{mmol} \mathrm{s}^{-1} \mathrm{~m}^{-2}$. The lowest light compensation point (where $I_{a}$ triggered a light-limited response for a given growth curve) was $109 \mathrm{mmol} \mathrm{s}^{-1} \mathrm{~m}^{-2}$, which occurs within the top $10 \mathrm{~cm}$ in even the dilute cultures. An inverse exponential relationship was found between $k_{\mathrm{B}}$ and biomass concentration.

\section{ACKNOWLEDGMENTS}

Appreciation is expressed for the many shared resources of our colleagues at the Energy Institute of Louisiana at the University of Louisiana campus; for the cooperation of the St. Mary Sugar Coop and access to their ponds; and for the internship funding under the Louisiana Sea Grant College Program which facilitated this research. This work was supported by the Louisiana Sea Grant College Program with funds from the National Oceanic and Atmospheric Administration Office of Sea Grant, Department of Commerce, USA.

\section{References}

1. Bourne, J. K., Clark, R., Green dreams, National Geographic 212 (2007) 38.

2. Chisti, Y., Biodiesel from microalgae, Biotechnol. Adv. 25 (2007) 294.

doi: http://dx.doi.org/10.1016/j.biotechadv.2007.02.001

3. U.S. DOE, National algal biofuels technology roadmap, U.S. Department of Energy, Office of Energy Efficiency and Renewable Energy, Biomass Program, Washington DC, 2010, pp. 1-140.

4. Dufreche, S., Zappi, M., Bajpai, R., Benson, B., Guillory, J., Today's lipid to renewable diesel fuel market, Int. J. Adv. Sci. Technol. 39 (2012) 49.

5. Metzger, P., Largeau, C., Botryococcus braunii: A rich source for hydrocarbons and related ether lipids, J. Appl. Microbiol. Biotechnol. 66 (2005) 486.

doi: http://dx.doi.org/10.1007/s00253-004-1779-z

6. Barajas-Solano, A. F., Guzman-Monsalve, A., Kafarov, V., Effect of carbon-nitrogen ratio on the biomass production, hydrocarbons and lipids on Botryococcus braunii UIS 003, Chem. Eng. Trans. 49 (2016) 247.

7. Benson, B. C., Gutierrez-Wing, M. T., Rusch, K. A., Optimization of the lighting system for a hydraulically integrated serial turbidostat algal reactor (HISTAR): Economic implications, Aquaculture Eng. 40 (2009) 45.

doi: http://dx.doi.org/10.1016/j.aquaeng.2008.11.001

8. Slade, R., Bauen, A., Micro-algae cultivation for biofuels: Cost, energy balance, environmental impacts, and future prospects, Biomass and Energy 53 (2013) 29. doi: http://dx.doi.org/10.1016/j.biombioe.2012.12.019

9. Sánchez Mirón, A., Cerón García, M.-C., Contreras Gómez, A., García Camacho, F., Molina Grima, E., Chisti, Y., Shear stress tolerance and biochemical characterization of Phaeodactylum tricornutum in quasi steady-state continuous culture in outdoor photobioreactors, Biochem. Eng. J. 16 (2003) 287.

10. Koller, M., Muhr, A., Braunegg, G., Microalgae as versatile cellular factories for valued products, Algal Res. 6 Part A (2014) 52.

11. Nonato, R. Montelatto, P., Rossell, C., Integrated production of biodegradable plastic, sugar, and ethanol, J. Appl. Microbiol. Biotechnol. 57 (2001) 1. doi: http://dx.doi.org/10.1007/s002530100732

12. Dias, M. O., Junqueira, T. L., Cavalett, O., Cunha, M. P., Jesus, C. D., Mantelatto, P. E, Rossell, C. E., Maciel Filho, $R$., Bonomi, A., Cogeneration in integrated first and second generation ethanol from sugarcane, Chem. Eng. Res. Des. 91 (2013) 1411.

doi: http://dx.doi.org/10.1016/j.cherd.2013.05.009 
13. Hermann-Krauss, C., Koller, M., Muhr, A., Fasl, H., Stelzer, F., Braunegg, G., Archaeal production of polyhydroxyalkanoate (pha) co- and ter-polyesters from biodiesel industry-derived by-products, Archaea (2013) 1. doi: http://dx.doi.org/10.1155/2013/129268

14. Travieso, L., Borja, R., Sanchez, E., Benitez, F., Dupeiron, $R$., Valiente, $V$., Chlorella vulgaris growth on pretreated cane sugar mill waste, Bull. Environ. Contam. Toxicol. 57 (1996) 986. doi: http://dx.doi.org/10.1007/s001289900287

15. Meyer, B. J., Benson, B. C., Ancelet, E. A., Bajpai, R., Zap$p i, M$. E., Investigation of the potential for using sugar mill wastewater to multiculture retention-pond microalgae for biomass and lipid production, Abstract No. 178, Aquaculture America Conference 2011, New Orleans, LA.

16. Lohrey, C., Kochergin, V., Biodiesel production from microalgae: Co-location with sugar mills, Bioresource Technol. 108 (2012) 76. doi: http://dx.doi.org/10.1016/j.biortech.2011.12.035

17. Aul and Associates, Inc., Emission factor documentation for ap-42 section 1.8: bagasse combustion in sugar mills, Contract No. 68-DO-0120, Office of Air Quality Planning and Standards, Office of Air and Radiation, U.S. Environmental Protection Agency, Research Triangle Park, NC, 1993.

18. Candelario, R. M., Santiago, F. D., Andrade, A. P., The treatment of liquid wastes from the cane sugar industry in Puerto Rico, Report to PR-WRRI, University of Puerto Rico-Mayaquez, PR, 1974.

19. Memon, A. R., Soomro, S. A., Ansari, A. K., Sugar industry effluent - characteristics and chemical analysis", J. Appl. Emerging Sci. 1 (2006) 152.

20. Siddiqui, W. A., Waseem, M., A comparative study of sugar mill treated and untreated effluent - a case study, Orient. J. Chem. 29 (2012) 1899. doi: http://dx.doi.org/10.13005/ojc/280451

21. Sahu, O. P., Chaudhari, P. K., The characteristics, effects, and treatment of wastewater in sugarcane industry, Water Qual. Exp. Health 7 (2015) 435.

doi: http://dx.doi.org/10.1007/s12403-015-0158-6

22. Clarens, A. F., Resurrection, E. P., White, M. A., Colosi, L. $M$., Environmental life cycle comparison of algae to other bioenergy feedstock, Environ. Sci. Technol. 44 (2010) 1813. doi: http://dx.doi.org/10.1021/es902838n

23. Parks, J. B. K., Craggs, R. J., Shilton, A. N., Wastewater treatment high rate algal ponds for biofuel production, Bioresource Technol. 102 (2011) 35.

doi: http://dx.doi.org/10.1016/j.biortech.2010.06.158

24. Wigmosta, M. S., Coleman, A. M., Skaggs, R. J., Huesemann, M. H., Lane, L. J., National microalgae biofuel production potential and resource demand, Water Resource Res. 47 (March 2011) W00H04, doi: 10.1029/2010WR009966. doi: http://dx.doi.org/10.1029/2010WR009966

25. Ulrich, A., Malle, D., Voora, V., Peak Phosphorus: Opportunity in the Making, Water Innovation Center, International Institute for Sustainable Development (IISD), Winnipeg, Manitoba, Canada, 2009.

26. Qiang, H. U., Faiman, D., Richmond, A., Optimal tilt angles of enclosed reactors for growing photoautotrophic microorganisms outdoors, J. Ferment. Bioeng. 85 (1998) 230. doi: http://dx.doi.org/10.1016/S0922-338X(97)86773-6

27. Zou, N., Richmond, A., Effect of light-path length in outdoor flat plate reactors on output rate of cell mass and of epa in Nannochloropsis sp., J. Biotechnol. 70 (1999) 351. doi: http://dx.doi.org/10.1016/S0168-1656(99)00087-5
28. Acien-Fernandez, F. G., Garcia-Camacho, F., Sanchez-Perez, J. A., Fernandez-Sevilla, J. M., Molina-Grima, E., Modeling of biomass productivity in tubular photobioreactors for microalgal cultures: Effects of dilution rate, tube diameter and solar irradiance, Biotechnol. Bioeng. 58 (1998) 605.

doi: http://dx.doi.org/10.1002/(SICI)1097-0290(19980620) 58:6<605::AID-BIT6>3.0.CO; 2-M

29. Goldman, J. C., Outdoor algal mass cultures - II: Photosynthetic yield limitations, J. Water Res. 13 (1979) 119. doi: http://dx.doi.org/10.1016/0043-1354(79)90083-6

30. Molina-Grima, E., Garcia Camacho, F., Sanchez Perez, J. A., Contreras Gomez, A., Valdez Sanz, F., Outdoor turbidostat culture of the marine microalga Tetraselmis $s p$., J. Aqua. Fish Manage. 25 (1994) 547.

31. Torzillo, G., Carlozzi, P., Pushparaj, B., Montaini, E., Materassi, $R$., A two-plane tubular photobioreactor for outdoor culture of Spirulina, Biotechnol. Bioeng. 42 (1993) 891. doi: http://dx.doi.org/10.1002/bit.260420714

32. Acien-Fernandez, F. G., Sanchez-Perez, J. A., Fernandez-Sevilla, J. M., Garcia-Camacho, F., Molina-Grima, E., Modeling of Eicosapentaenoic Acid (EPA) production from Phaeodactylum tricornutum cultures in tubular photobioreactors: Effects of dilution rate, tube diameter, and solar irradiance, Biotechnol. Bioeng. 68 (2000) 173.

doi: http://dx.doi.org/10.1002/(SICI)1097-0290(20000420) 68:2<173::AID-BIT6>3.0.CO; 2-C

33. Steele, J. H., Primary production in aquatic environments, in Notes on Some Theoretical Problem in Production Ecology, C. R. Goldman, Mem. Inst. Idrobiol., University of California Press, Berkeley, CA, 1965, pp. 383-398.

34. Steele, J. H., Microbial kinetics and dynamics, in Lapidus, L. and Amundson, N. (eds.), Chemical Reactor Theory, Prentice-Hall, Englewood Cliffs, NJ, (Chapter 7), 1977, pp. 405-483.

35. Vonshak, A, Laorawat, S., Bunnag, B, Tanticharoen, M., The effect of light availability on the photosynthetic activity and productivity of outdoor cultures of Arthrospira platensis (Spirulina), J. Appl. Phycol. 26 (2014) 1309. doi: http://dx.doi.org/10.1007/s10811-013-0133-1

36. Ryther, J. H., Potential productivity of the sea, Science $\mathbf{1 3 0}$ (3376) (1959) 602. doi: http://dx.doi.org/10.1126/science.130.3376.602

37. Benson, B. C., Gutierrez-Wing, M. T., Rusch K. A., The development of a mechanistic model to investigate the impacts of the light dynamics on algal productivity in a hydraulically integrated serial turbidostat algal reactor (HISTAR), Aquacultural Eng. 36 (2007) 198. doi: http://dx.doi.org/10.1016/j.aquaeng.2006.12.002

38. Richmond, A., Boussiba, S., Vonshak, A., Kopel, R., A new tubular reactor for mass production of microalgae outdoors, J. Appl. Phycol. 5 (1990) 327.

doi: http://dx.doi.org/10.1007/BF02186235

39. Hu, Q., Kurano, N., Kawachi, M., Iwasaki, I., Miyachi, S., Ultrahigh-cell-density culture of a marine green alga Chlorococcum littorale in a flat-plate photobioreactor, Appl. Microbiol. Biotechnol. 49 (1998) 655. doi: http://dx.doi.org/10.1007/s002530051228

40. Drapcho, C. M., Brune, D. E., The partitioned aquaculture system: Impact of design and environmental parameters on algal productivity and photosynthetic oxygen production, Aquacultural Eng. 21 (2000) 151. doi: http://dx.doi.org/10.1016/S0144-8609(99)00028-X

41. Molina-Grima, E., Acien-Fernandez, F. G., Garcia-Camacho, F., Camacho-Rubio, F., Christi, Y., Scale-up of tubular photobioreactors, J. Appl. Phycol. 12 (2000) 355. doi: http://dx.doi.org/10.1023/A:1008110819338 
42. Rossignol, N., Lebeau, T., Jaouen, P., Robert, J. M., Comparison of two membrane-photobioreactors, with free of immobile cells, for the production of pigments by a marine diatom, Bioprocess Eng. 23 (2000) 495 doi: http://dx.doi.org/10.1007/s004499900186

43. Benson B. C., Gutierrez-Wing, M. T., Rusch K. A., Application of the Fourier method to differentiate biological rhythms from stochastic processes in the growth of Selenastrum capricornutum Printz: Implications for model development, J. Appl. Phycol. 20 (2008) 103. doi: http://dx.doi.org/10.1007/s10811-007-9187-2

44. APHA, Standard Methods for the Examination of Water and Wastewater, $19^{\text {th }}$ Edition, American Public Health Association, Washington DC, 1998.

45. Bligh, E. G., Dyer, W. J., A rapid method of total lipid extraction and purification, Can. J. Biochem. Physiol. 37 (1959) 911

doi: http://dx.doi.org/10.1139/o59-099

46. Kirk, J. T., Light and Photosynthesis in Aquatic Ecosystems, Ed. 2, Cambridge University Press, Cambridge, UK, 1994, pp. 509. doi: http://dx.doi.org/10.1017/CBO9780511623370

47. Rebolloso-Fuentes, M. M., Garcia-Sanchez, J. L., Fernandez-Sevilla, J. M., Acien-Fernandez, F. G., Sanchez-Perez, J. A., Molina-Grima, E., Outdoor continuous culture of Porphyridium cruentum in a tubular photobioreactor: Quantitative analysis of the daily cyclic variation of culture parameters, J. Biotechnol. 70 (1999) 271. doi: http://dx.doi.org/10.1016/S0168-1656(99)00080-2
48. Molina-Grima, E., Acien-Fernandez, F., Garcia-Camacho, F., Christi, Y., Photobioreactors: Light regime, mass transfer, and scale-up, J. Biotechnol. 70 (1999) 231. doi: http://dx.doi.org/10.1016/S0168-1656(99)00078-4

49. Fabregas, J., Patiño, M., Arredondo-Vega, B. O., Tobar, J. L., Otero, A., Renewal rate and nutrient concentration as tools to modify productivity and biochemical composition of cyclostat cultures of the marine microalga Dunaliella tertiolecta. Appl. Microbiol. Biotechnol. 44 (1995) 287. doi: http://dx.doi.org/10.1007/BF00169918

50. Fernández-Reiriz, M. J., Labarta, U., Albentosá, M., Pérez-Camacho, A., Effect of microalgal diets and commercial wheatgerm flours on the lipid profile of Ruditapes decussates Spat, Comp. Biochem. Physiol. Part A: Molecular \& Integrative Physiol. 119 (1998) 369. doi: http://dx.doi.org/10.1016/S1095-6433(97)00429-7

51. Toerien, D. F., Haung, C. H., Algal growth prediction using growth kinetic constants, Water Res. 7 (1973) 1673. doi: http://dx.doi.org/10.1016/0043-1354(73)90135-8

52. Reynolds, J. H., Middlebrooks, E. J., Porcella, D. B., Grenney, $W . J$. , Effects of temperature on growth constants of Selenastrum capricarnutum, J. WPCF 47 (1975) 2420.

53. Juneja, A., Ceballos, R. M., Murthy, G. S., Effects of environmental factors and nutrient availability on the biochemical composition of algae for biofuels production: A review, Energies 6 (2013) 4607. doi: http://dx.doi.org/10.3390/en6094607

54. Mascarelli, A. L., Gold rush for algae, Nature 461 (7263) (2009) 460.

doi: http://dx.doi.org/10.1038/461460a 